J. B. Lal, A. K. Ghosh: ibid., 11, 75 ('55).

61) J. B. Lal, S. P. Srivastava, D. Prakash: J. Proc. Oil Technol. Ass., India, 12, 68 ('56); 62) S. P. Srivastava, D. Prakash, J. B. Lal: ibid., 12, 95 ('56); 63) M. C. Joshi, R. C. Srivastava, J. B. Lal: ibid., 12, 41 ('56): 64) K. Navain, J. B. Lal: ibid., 12, 135 ('56); 65) G. M. Mathur, J. B. Lal, W. N. Nigam, S. N. Kapoor: ibid., 12. $115\left({ }^{\prime} 56\right)$; 66) J. B. Lal: J. Instn. Chem.,

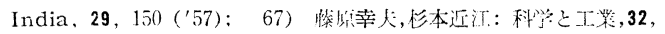
265 ('58); 68) L. Fibranz, M. I. Blake, C. E. Miller: J. Am. Pharm. Assoc., 47, 133 ('58); C. A., 52, 8469h; 69)

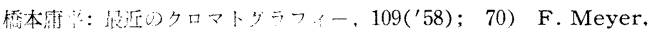
E. Meyer: Arch. Pharm., 290,109, ('57); C. A., 51, 11660c.

71) J. P. Butler, T. P. Czepiel: Anal. Chem., 28, 1468 ('56): 72) 近将幸夫：菻结，76，1077 ('57); 73) B. K. Ganguly, P. Bagchi: J. Org. Chem., 21, 1415 ('56); 74) H. Böhme, T. Severin: Arch. Pharm., 290, 405, 448, 486 ('57); C. A., 52, 81h; 75) D. P. Chakraborty, P. K. Bose: J. Indian Chem. Soc., 33, 905 ('56); C. A., 51, 10006i; 76) W. L. Stanley, S. H. Vannier: J. Assoc. Offic. Agri. Chem., 40, 562 ('57); 77) 橋本輠小: 最近のク ロマトグラフィー, 112 ('58); 78) J. R. Clopton: J. Agri. Food Chem., 6, 457 ('58); 79) A. H. J. Cross, A. H. Gunn. S. G. E. Stevens: J. Pharm. Pharmacol., 9, 841 ('57): 80) F. H. L. van Os, J. H. Zwaving: Pharm. Weekblad, 91, 805 ('56).

81) J. Holubek: Pharm. Zentralh., 95, 129 ('56); 82) Trifonow: Ind. Parfumene, 11, 281 ('56); 83) E. Knobloch, K. Hejno, Z. Arnold, K. Mnnoucek, Z. Bacík: Céskosl. Farm., 6, 24 ('57); 84) A. Liberti: Riv. ital. essenze, Profumi, Piante Offic. Oil vegetali, Saponi, 39, 67 ('57); C. A., 51, 11660h； 85) 任藤寿：徫生就，74，33

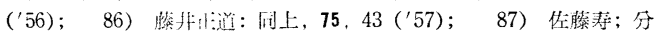
化, 6, 551 ('57); 88) R. H. Boyd, A. R. Amell: Anal. Chem., 28, 1280 ('56); 89) D. H. E. Tattje: Pharm. Weekblad, 92, 723, 729 ('57); 90) K. L. Surve: Perfum. Essent. Oil Rec., 48, 625 ('57).

91) W. L. Stanley, R. C. Lindwall, S. H. Vannier: Agri. \& Food Chem., 6, 858 ('58); 92) F. La Face, M. D. Riganesis: Ricera Sci., 26, 819('56); C. A., 50, 14202d; 93) K. L. Surve, K. K. Chakravarti, S. C. Bhattacharyya: Perfum. Essent. Oil Rec., 49, 624 ('58); 94) D. H. E. Tattje: Pharm. Weckblad, 91, $733\left({ }^{\prime} 56\right)$; 95) F. H. L. van Os, C. Scholtens: Riechstoffe u. Aromen, 8, 265 ('58); 96) F. H. L. van Os, C. Scholtens: Parfum. Cosmét. Savons, 13, 14 ('58); 97) D. H. E. Tattje: Pharm. Weekblad, 93, 1048 ('58); 98) J. B. Stenlake, W. D. Williams: J. Pharm Pharmacol., 9, 900 ('57); 99) N. S. Kapur, K. M. Narayanan, G. S. Bains, D. S. Bhatia: Chem. \& Ind., 38, 1272 ('57); C. A., 52, 1862d; 100) L. E. Eryklöf: Farm. Revy, 56, 733 ('57); C. A., 52, $2342 \mathrm{~d}$.
101) J. Petránek, M. Vecérá: Chem. Listy, 51, 1686 ('57); 102) R. A. Braun, W. A. Mosher: J. Amer. Chem. Soc., 80, 2749 ('58); 103) L. G. Ensminger: J. Assoc. Offic. Agri. Chem., 41, 613 ('58); 104) 拈本洋: 话 脸技協講, 21, 82('56); 105) E. Balcarówna, B. Borkowski: Bull. Inst. Roslin Leczniczych, 5, 21 ('59); 106) S. H. Newburger, M. A. Hall, J. H. Jones: J. Assoc. Offic. Agri. Chemists, 41, 668 ('58); C. A., 53, 2542d; 107) N. E. P. Roura: Publs. inst. invest. microquím., Univ. nacl. litoral, 22, 169 ('56); C. A., 51, 13319g; 108) F. Meyer: Perfum. Essent. Oil Rec., 49, 424 ('58); 109) I. Simonyi, G. Tokár: Magyer Kém. Foly., 63, $210\left({ }^{\prime} 57\right)$; 110) D. T. Englis: J. Assoc. Offic. Agri. Chem., 41, 203 ('58).

111) 南崎良明: 桨学研究, 30, 506 ('58); 112) O. H. Wheeler, J. L. Mateos: Anal. Chem., 29, 538 ('57); 113) 北鼠正栄，小营四二：樟脳技協講，21，95 ('56)；114）北泉正栄， 小久保悌子, 高橋計之助, 竹下管一: 哲売研, 101，244 ('59); 115) T. Hiraizumi, A. Komatsu: Perfum. Essent. Oil Rec., 48,

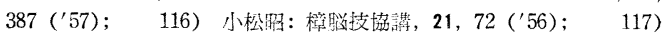
D. F. Eggers, W. E. Lingren: Anal. Chem., 28, 1328 ('56); 118) S. Pinkas: ibid., 29, 334 ('57); 119) E. Sundt, W. Winter: ibid., 30, 1620('58); 120) F. Vonásek: Prumysl Potravinárský, 9, 315 ('58); C. A., 52, 20902h.

121) I. M. Panayotov: Perfum. Essent. Oil Rec., 49, 231 ('58); 122) A. Weissenberg, D. Ginsberg: Bull. Res. Counsil, Israel, 5A, 268 ('56); 123) O. Theander: Acta, Chim. Scand., 11, 717 ('57); 124) P. H. Joppien: Z. Lebensm.-Untersuch. u. Forsch., 104, 393('56); C. A., 51, 6954h; 125) E. V. Zobov, Y.S. Lyalikov: Zhur. Anal. Khim., 11, 459 ('56); 126) E. V. Zobov, Y. S. Lyalikov: Izvest. Akad. Nauk Turkmen. S. S. R., 93 ('58); C. A., 52, 14431h; 127) T. Higuchi, C. H. Barnstein: Anal. Chem., 28, 1022 ('56); 128) G. Gabrielson: J. Appl. Chem., 7, 533 ('57); 129) P. G. Peranik: Current Sci.

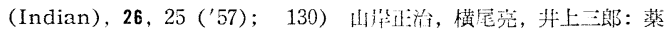
誌, 75, 1383 ('55).

131) R. A. Friedel: Anal. Chem., 28, 940 ('56); 132) A. G. Sharkey: ibid., 28, 1337 ('56); 133) A. Kolusheva, A. Morozova: Farmatsiya, Bulgaria, 7, 27 ('57); 134) M. Rothe, I. Voigt: Ernährungs Forschung, 2, 444 ('57); 135) 近藤幸大: 薬誌, 77, 694 ('57); 136) 古川䰻：日化, 80,

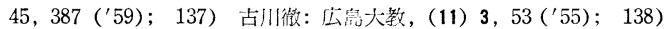
林敬一郎, 橋本庿平: Pharm. Bull., 50, 74, 611 ('57); 139)

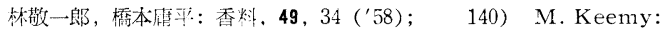
Anal. Chem., 29, 1489 ('57).

141) D. Ivanov, C. Ivanov, N. Marecova, I. Ognianov: Acta. Chim. Acad. Sci. Hung., 14, 163 ('58); 142) L. Levi: Perfum. Essent, Oil Rec., 49, 512 ('58); 143) 辰

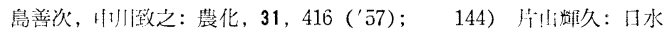
商, 24, 205, 346, 955 ('58); 145) 抑辉久: 间上, 24, 511

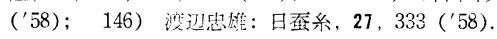

\title{
18 界面活性成
}

伊沢康司・木村和三 郎*

まえがき 界酒活性剂の分析注注成分と副成分の定性 と定量とに大别心机る。主成分は䧔イオン，陽イオン， 兩性㧍よび非イオン活性剂, ならびにその組合せの二元，

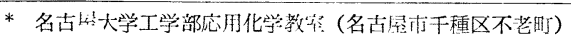

三元活性剂に分類され，副成分泟水分，油脂鉱油数，無

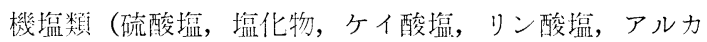
リ類), 有機物 ( $\mathrm{CMC}$, 染料, ケイ光標白用など), その 他の添加剤よりなる。界面活性剂の分析に関しては多く 
の報文がある. 分析法は, 重量法(分解, 抽出, 沈殿法) と容量法とよりなる化学分析法の外に, スペクトル分析 法 (UV, IR, X 線, 質量), クロマトグラフ法, 光電比 色法, 電導度, 電位差润定法, ラジオトレーサ一法など の機器分析法が取入れられている. 本文は主として, 1958 年〜1959 年に発表された報交の紹介である.

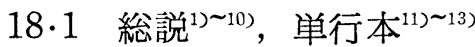

㓌イオン, セッケン, 非イオン, 陽イオン活性用の分 離, 定性, 定量に関する往来の分析法の紹介に加えて, 直接滴定法，あるいは，非水溶媒中での滴定によるセッ ケンの定量，第 3 級，あるいは，4 級アミン塩定量法の 陽イオン活性剤分析への応用，ヒドロキシル化合物，ポ リグリコールエーテル，㐫るいは，エステル類の分析法 の非イオン活性剤分析への态用などの紹介6), 抽出法, 比色法, 陰イオン一陽イオン活性剤滴定法, イオン交換 法, 沈殿法などによる界面活性剤の定量およで無機塩の 定量7), 非イオン活性浏分析に関する総説 ${ }^{8}$, ドイツ, ア メリカに拈りる石油系スルホン酸塩の標準分析法9), IR および UV スペクトルグラフ法による界面活性阂の分 析10)などの総説があり，その他の著書11)12)にも分析法が 集録されているか，最近，系統的界面活性剂分析法13) が出た。

\section{$18 \cdot 2$ 化学分析法}

イオン性活性剂, 院イオン活性剤・ベンジジン錯塩の

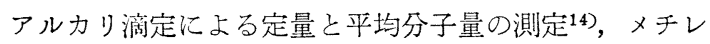
ンブルー法 ${ }^{15}$ による陰イオン活性分の定量, 石油エーテ ル,あるいは $n$-ペンタンによる中性油分の抽出，カール フィッシャー法による水分定量など市販アルキルベンゼ ンスルホン酸ナトリウムの全分析16), p-トルイジン法17) による第 2 級アルコール硫酸ナトリウムの定量 ${ }^{18)}$, さら に, 吸着指示薬写もちいる分析法としては, エリスロシ ンあるいは，エオシンを吸着指示薬，クロロホルム多抽 出溶剤として，陽イオン活性威滴定液でアルキル硫酸塩 あるいは，アルキルアリールスルホン酸塭を滴定与るエ リスロシン, あるい注, エオシン法19), トルイジンブルー が $\mathrm{pH}=7$ 以上の水溶液に叔て，クロロホルムが共存 与ると紅色色素塩基となったクロロホルム層に移行子る が，陰イオン活性戍のコン跡の添加によりその塩となっ てクロロホルム贋法青色着色与る事実より, 陰イオン

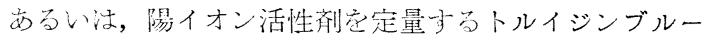
法20) などあり，また，アルキル基 $\mathrm{C}_{8}$ 以上の有譏スル

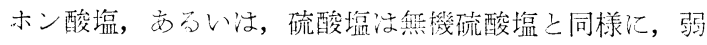

酸性水溶液中, $4-ア \sum ノ-4^{\prime}-$ ロ ルビフェニル塩酸塩 (ACB) と錯塩を作ることにより，両者の ACB 錯塩を アルカリ滴定し，さらに，キレート滴定により無機硫酸 塩を求めることにより陰イオン活性剤を定量するキレー 卜滴定・4-アミノ-4'-クロルビフェニル塩酸壏汒法， クロルフルオレセイン銀滴定法 ${ }^{22)}$, ブロムクレゾールグ リン酸滴定法による高分子量第 4 級アンモニウム塩製品 の主成分，アミン塩酸塩，遊離アミン， $\mathrm{NaCl}$ の定量 法 ${ }^{23)}$, ビニル乳濁液中の陰イオン活性剂を乳濁液の白濁 性，抢よび共存する無機塩の影響をうけることなくメチ レンブルー分相逆滴定法 ${ }^{24}$ により定量する研究25などが ある.

非イオン活性剤・Greenwald らがさきに報告した ジオキサン・ベンゼン芯溶剤として，ポリエチレンオキ シド系非イオン活性刜在水で滴定し，活性剤の HLB, およびエチレンオキシド含有量を求める方法26)を改良し て，溶剤としてジメチルホルムアミド・ベンゼンをもる いた再現性のよい，エーテル型ポリエチレンオキシド系 非イオン活性剤の迅速定量法27，グリコール，あるいは， ポリグリコールエーテル，またはエステル中のアルキレ ンオキシドをヨウ化水素酸により開裂し, 遊離する当量 のヨウ素をチオ硫酸ナトリウム溶液で滴定しアルキレン オキシド含有量を求めるオ法28)などあり，また，ポリエ チレンオキシドラウリルエーテルとヨウ化ビスマスカリ ウムとの錯塩， $\mathrm{Ba}^{2+}$ の存在で各種へテロポリ酸，ヨウ 化ビスマスカリウム, チオシアン酸ビスマスカリウム, およびテトラフェニルホウ酸ナトリウムとの䤠塭がもつ とも水難溶性一沈殿生成感度が高く，彷って，非イオン

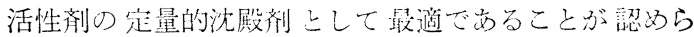
れ29)，さらに，非イオン活性凨のバリウムリンタングス テン酸錯塩法による主成分絶対量の定量 ${ }^{30}$ ，また，活性 剤々セルヘのブロムチモールブルー指示薬の吸着によう 変色に基ずく非イオン活性剤の定量 ${ }^{31)}$, 非イオン活性 剤・セッケン・舆機塭混合物中よりジオキサンで活泾:分 を抽出し，リンモリブデン酸に゙非イオン活性剂との鏵掹 を作りせ, 沈殿, 沪過, 乾燥, ひよう量し活性刜定算出 するオ法32)，また，ボリエチレングリコールいのLabat

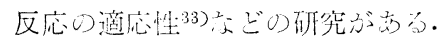

\section{$18 \cdot 3$ 機器分析法}

$18 \cdot 3 \cdot 1$ イオン交換樹脂をもちいる方法 $\mathrm{BaSO}_{4}$ 注 キレート試薬，たとえば，エチレンジアミン四酰酸二 ナトリウム塭と反応しない势，陰イオン活性剂の $\mathrm{Ba}$ 塩定量的に反応して陰イオン活性戍ナトリウム塩と

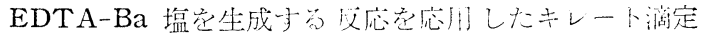


法と陽イオン交換法とを組合せ，陰イオン活性威および 共存する硫酸塩を定量するキレート滴定・陽イオン交換 法34), その改良法であるメタルフタレイン・EDTA法35), 本法之酸分解法との組合せによる硫酸エステル型, 和上 び，スルホン酸型活性棛, およで, 共存するボー硝の分別

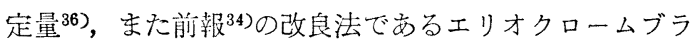
ックT・ジエチレントリアミン五酢酸法, メタルフタレ イン・ジエチレントリアミン五酶酸法37)などの一連の研 究, イオン性活性剂水溶液定温時, Zeo-Karb $225(\mathrm{H}$ 型）イオン交換塔を通し，流出液をアルカリ滴定して活

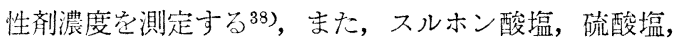
セッケン，あるいは，それらの混合物のアルコール溶液

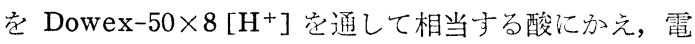
位差滴定により定量する, あるい注, スルホン酸塩, セ ッケン, 非イオン活性剤の三元活性戍アルコール溶液を Dowex $-50 \times 8\left[\mathrm{H}^{+}\right]$, Dowex $-1 \times 2\left[\mathrm{Ac}^{-}\right]$, Dowex -2 $\times 8\left[\mathrm{OH}^{-}\right]$究順次通し, 流出液加ら非イオン活性剂を, Dowex- $1 \times 2\left[\mathrm{Ac}^{-}\right]$から滥酸アルコール溶液でスルホ ン酸艺溶離させ, Dowex- $2 \times 8\left[\mathrm{OH}^{-}\right]$から同様にして 脂肪酸を溶離して, そ机ぞれ定量する方法 ${ }^{39}$, Dowex$50 \times 4\left[\mathrm{H}^{+}\right]$(強酸型陽イオン交換樹脂) と Duolite A-7 (弱塩基型陰イオン交換樹脂)妾併用することによりエチ レンオキシド系非イオン活性戍とドデシルベンゼンスル ホン酸ナトリウムとの二元性剂の分離定量を試み, 流出 液から非イオン活性戍, Duolite A-7 交換塔から塩 析法によりドデシルベンゼンスルホン酸ナトリウム艺溶 離し定量する40), また, 強酸型陽イオン交換樹脂の代わ り汇弱酸型陽イオン交換樹脂 Lewatit CN $206\left[\mathrm{H}^{+}\right]$ をもちいることにより，陽イオン活性郕（アルキルベン ジル・ジメチル・アンモニウムクロリド）と非イオン活 性剂々の二元活性剂の各成分活性剂の分離定量に好結果 を觉 ${ }^{41}$ ，また，アルキル硫酸塩，脂肪酸アルカノールア ミン塩心ど它含きシャンプーの酸性アルコール溶液を弱 塩基型イオン交換樹指 Amberlite CG 45 Type 2 を 通し, 流仙液中心脂肪酸アルカノールアミン塩と脂肪酸 を, アミン埧はアセトン抽出, 脂肪酸はクロロホルム抽 出で定量し, 交換塔からはアンモ二ャ・アルコールで除

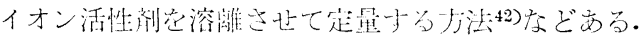

$18 \cdot 3 \cdot 2$ ペーパークロマトグラフィー＼cjkstart陰イオン活

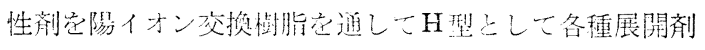
で展開し，さらに，アルカリ处理，酸処理後に同様にし て展開し，ピナクリプトールエローにより発色させ，ス ポットの有無, 位置上り陰イオン活性郕定定性与る43), あるいは，パラフィン処理したクロマト用沪紙をも方 い, ショ糖脂肪酸エステルのモ, エステルとジ一, トリ
一，ポリステルとの分離定性 ${ }^{44) ， ま た ， ア ル カ ノ ー ル ~}$ アミン類の分離 ${ }^{45}$ ), 夕モールの合成における $\beta$-ナフタ リンスルホン酸の検出46)などがある.

18.3.3 カラムクロマトグラフィー クロロホルム アセトン空溶離戍として，ケイ酸カラム觉も台い，ホリ エチレンオキシドオクチルフニノール落各成分に分離し ている47).

18.3.4 ガスクロマトグラフィー 活性剂の疎水部 の定性にガスクロマトグラフィーを適用した興味ある研 究がある。すなわち, 疎水部定性のためのリン酸酸分解 により芳香族スルホン酸塩, $n$-アルキル硫酸塩, 脂肪酸 アミド, 脂肪酸エステルなどは出発䟢水部原料に分解し, ポリエチレンオキシド脂肪アルコール注相当するオレフ インに, ジオクチルスルホコ八ク酸エステルはオクチル アルコールとオレフィンに分解するが， $\alpha$-スルホ脂肪 酸, アルカンスルホン酸などは所期の分解が起らないこ となど明らかにされた43)。

18.3.5 UV スペクトルグラフィー UVの界面活 性剂分析への利用注, Tall 油, 高度不飽和酸誘導体, アルキルアリールスルホン酸㫫, ポアルキレンオキシ ドアルキルフェノール, ピリジニウム塧, 不飽和異理環 状化合物などの分析汇限られるが，良来の化学的定性分 析に UV スペクトルグラフィーを組合せた簡単かつ的 確な系統的定性分析法方゙報告され49), また, 四洗い, 液 体洗浏, 工業洗剤中のアルキルアリールスルホン酸掹の 定量50がある。

18·3・6 IR スペクトルグラフィーＩR は界面活性 剤の踪水部の構造的追跡, 陰イオン活性剤の定量, 非イ オン活性剤中のエチレンオキシド鎖長の検討などにも台 いられる.1953年にアメリカの標準法が発表され ${ }^{51}$ ， ま た，水溶液中の微量のアルキルベンゼンスルホン酸塩の 定量 ${ }^{52}$, 廃水中のアルキルベンゼンスルホン 酸塩の定 量 ${ }^{53)}$, など実用面への利用があり, さらに, 口ウ, 樹脂, ポリマー，乳化剤定含旮乳化ツヤ出し剂中の乳化剂，た とえば, オレイン酸ナトリウム, Tween 20, 非イオン活 性剂の確認 ${ }^{54)}$, Detergent-Slurry のIR 定量分析デー タ55)，また，IR スペクトルグラフィーにおけるアルキ ル硫酸バリウム，スルホン酸バリウムなど Ba-塭の妥当 性 ${ }^{56)}$, 店どの研究報告がある.

$18 \cdot 3 \cdot 7$ 光電比色法 第 4 級アンモ二ウム塩とメチ ルオレンジとの複合体 $(1: 1)$ をクロロホルムで抽出し て，四光度を測定し陽イオン活性郕を定量与る5 素デンプン呈色法58)の Tween 20,40,60, 80, Emalgen 106 分析への忘用59), Longwell, Maniece 法60)の河川, 廃水中の陰イオン活性剤定量への応用61), 立た, 綏衡液 
中，ラウリル硫酸 ナトリウムを 0 -トルイジンのハロキ ノンとの反応により発色 $\left(\lambda_{\max }=590 \mathrm{~m} \mu\right)$ させ, 吸光 度を測ることより陰イオン活性剤を定量する62)などのほ か, アルキルアレンスルホン酸塩, あるいは, スルホコ ハク酸エステルの濁度滴定法による定量63)なとがある.

$18 \cdot 3 \cdot 8$ 電位差, 電導度滴定法 非イオン活性剤定 量の Schönfeldt 法64) ゙゙フェロシアン酸カリウムの過 剩堂電位差滴定で求め ${ }^{65)}$, また，プロピオン酸溶媒中， $\mathrm{HClO}_{4}$ ・無水プロピオン酸溶液の電位差滴定による第 4 級アンモニウム八ライドの定量66)などあり, また, ビニ ル乳罚液中の脂肪酸セッケン67), 脂肪アミン塩 ${ }^{68) な と ゙ の ~}$ 非イオン活性剤溶液中電導度滴定による定量法などがあ 不.

\section{$18 \cdot 3.9$ 炎光分析法 活性剂中のボウ硝を $\mathrm{BaSO}_{4}$} として炎光分析により定量する興味ある研究69)がある.

芑子び 界面活性剤の分析は, 確認, 定量が最近, 化 学分析, および, 機器分析の発達に伴い迅速, 簡単, か つ，正確になってきたが，成分分離はなお，困難を伴う 場合が多く，多元混合活性剤の分析とともに，今後の研 究が期待される。

\section{交 献}

1) J. C. Harris, R. Bernstein: Bibliographical Abstracts of Methods of Analysis of Synthetic Detergents, 1888 1956, ASTM Special Technical Publication No. 150A ('56); 2) W. G. Spangler: J. Am. Oil Chemists' Soc., 34, 191 ('57); 3) R. Neu: Fette u. Seifen, 59, 503 ('57); 4) H. Holness, W. R. Stone: Analyst, 82, 166 ('57); 5) J. C. Harris: Chem. Specialties Mfrs. Assoc., Proc., Dec.,('57); C. A., 52, 15098 ('58); 6) S. Siggia: J. Am. Oil Chemists' Soc., 35, 643 ('58); 7) W. B. Smith: Analyst, 84, 77 ('59); 8) S. Siggia: Soap, 34, (3), 51, 133 ('58); 9) W. F. Maass, E. BuchspiessPaulentz, F. Stinsky: Seifen-Öle-Fette-Wachse, 54, 575 ('58); 10) Mrs. Gatineau: Rev. fraç. corps gras, 5, 254, ('58); C. A., 52, 14199 ('58).

11）三雲次郎,浅原照三, 今井怡知朗: “石酹·界面活性剤”, ('59), (日刊工業新聞社, 東京)；12） A. M. Schwartz, J. W. Perry, J. Berch: "Surface Active Agents and Detergents", Vol. II, ('58), (Interscience Publisher Inc., New York); 13) M. J. Rosen, H. A. Goldsmith: Chemical Analysis, Vol. 12, "Systematic Analysis of Surface Active Agents", ('60), (Interscience Publisher Inc., New York); 14) W. Kling, F. Püssel: Melliand-Textilberichte, 18, 21 ('34); 15) S. R. Epton: Nature, 160, 795 ('47); Trans. Faraday Soc., 44, 226 ('48); 16) E. W. Blank: Soap, 34, (1), 41, 107 ('58); 17) H. Stüpel, A. von Segesser: Helv., 34, 1362 ('51); Fette u. Seifen, 53, 260, 327 ('51);
18) I. K. Getmanski : Masloboino-Zhirovaya Pam., 25, (7), 29 ('59); C. A., 53, 20848 ('59); 19) 苚木 大, 岶 山楊治: 薬誌, 79, 522 ('59); 20) 同上, 79, 526 ('59).

21）原田哲弥，木村和三郎：油化学， 7, $200\left({ }^{\prime} 58\right)$; 22) A S. Dubois: Ind. Eng. Chem., Anal. Ed., 17, 744 ('45); 23) M. Babcock, D. E. Terry, A. J. Milun: J. Am. Oil Chemists' Soc., 36, 93 ('59); 24) 伊沢康司, 木村和三郎: 油化学, 9, $124\left({ }^{\prime} 60\right)$; 25) 浦重䉝：间上, 8, $\left.625\left({ }^{\prime} 59\right) ; 26\right)$ H. L. Greenwald, G. L. Brown, M. N. Fineman: Anal. Chem., 28, 1693 ('56); 27) L. E. Weeks, J. T. Lewis, M. E. Ginn: J. Am. Oil Chemists' Soc., 35, 149 ('58); 28) S. Siggia, A. C. Starke, Jr., J. J. Garis, Jr., C. R. Stahl: Anal. Chem., 30, 115 ('58)；29）原田哲莏，木村和三郎：油 化学, 8, 523, ('59); 30) W. Kimura, T. Harada: Fette u. Seifen, 61, 930 ('59).

31) K. Peter: Fette u. Seifen. 61, $45\left({ }^{\prime} 59\right)$; 32) C. B Stuffins: Soap, Perfumery \& Cosmetics, 31, 369 ('58); 33) C. J. Turri: Rend. ist. super. sanità, 22, 174 ('59); C. A., 53, 18516 ('59); 34) 原田暂弥, 木村和三郎: 油化学, 7, $77\left({ }^{\prime} 58\right)$ ； 35) 同上, 7, 142 ('58); 36) 同上, 7, $149\left({ }^{\prime} 58\right)$; 37) 同上, 7, 195 ('58); 38) G. Russel, E. Whittaker: Analyst, 84, 253 ('59); 39) P. Voogt: Rec. Trav. Chim. Pays-Bas, 77, 889 ('58); 40) M. E. Ginn, C. L. Church: Anal. Chem., 31, 551 ('59).

41) H. Hempel, H. Kirschneck: Fette u. Seifen, 61, 369 ('59); 42) S. H. Newburger: J. Assoc. Off. Agr Chemists, 41, 664 ('58); 43) 山本语而, 小林沉, 鼠本 敬: 工化, 62, 1549 ('59); 44) H. P. Kaufmann, J. Walther: Fette u. Seifen, 61, 782 ('59); 45) E. Heinerth, J. Pallerberg: ibid., 61，376 ('59); 46) 根来健二, 出原正孝, 岸本 卓, 檜山八郎, 大鳥敬治: 工化, 62, 846 ('59); 47) J. Kelley, H. Greenwald: J. Phys. Chem., 62, 1096 ('58); 48) J. D. Knight, R. House: J. Am. Oil Chemists' Soc., 36, 195 ('59); 49) V. W. Reid, T. Alston, B. W. Young: Analyst, 80, 682 ('55); 50) R. M. Kelley, E. W. Blank, R. Fine, W. E. Thompson: ASTM Bull. No. 237, TP 90 ('59).

51) P. Sadtler: ASTM Bull. No. 190, 51 ('53); 52) E. M. Sallee et al.: Anal. Chem., 28, $1822\left({ }^{\prime} 56\right)$; 53) J. D. Fairing, F. R. Short: ibid., 28, 1827 ('56); 54) J. E. Murphy, W. C. Schwemer: ibid., 30, 116 ('58); 55) V. A. Cirillo: ibid., 31, 959 ('59); 56) J. W. Jenkins, K. O. Kellenbach: ibid., 31, 1673 ('59); 57) G. Nebbia: Chim. e Ind., 40, 638 ('58); A. A., 6, \# 1089 ('59); 58) R. V. MacAllister, R. T. Lisk: Anal. Chem., 23, 609 ('51); 59) 岡野定輔，松原明子：薬剂学，18，33 ('58); 60) J. Longwell, W. D. Maniece: Analyst, 80, 167 ('55).

61) J. G. Slack: Analyst., 84, 193 ('59); 62) H. D. Graham, R. McL. Whitney: Anal. Chem., 31, 1673 ('59); 63) R. Wickbold: Seifen-Öle-Fette-Wachse, 85, 415 ('59); 64) N. Schönfeldt: Nature, 172, 820, ('53); J. Am. Oil Chemists' Soc., 32, 77 ('55); 65) M. Roussos, H. Passedouet, J. Cariou: Rev. franç. corps gras, 5, 13('58); C. A., 52, $7740\left({ }^{5} 58\right)$; 66) C. Hennart, E. Merlin: Chim. Anal., 40, (5), 167 ('58); A. A., 6, \# 1088 ('59); 67) 三浦重義：油化学，8，459 ('59); 68) 三浦重我：同上, 8, 518 ('59); 69) D. C. Cullum, D. B. Thomas: Analyst,

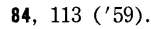

